\title{
PROBLEMS OF PLURALISM IN MODERN INDONESIAN ISLAM
}

\author{
Faisar Ananda Arfa \\ IAIN Sumatera Utara - Indonesia | faisar_nanda@yahoo.co.id
}

\begin{abstract}
Different from Western Europe, in which democracy and pluralism are achieved by eliminating the role of religion in politics and public sphere, religion in Indonesia plays a positive role. However, the main stumbling block of this positive role is the faulty assumptions and suspicions among Indonesian Muslims about the concept of "the other", be it internally among Muslims or externally with the non-Muslims. Stereotypical terms such as "extreme Islam" (terrorist Islam) and "Christian-Catholic conspiracy" have resulted in disastrous consequences in society and do not at all support positive change towards democracy and pluralism. This article discusses how pluralism is, perceived, understood and practiced in Indonesia by Muslims. The author argues that it is the responsibility of Indonesian Muslim leaders to reexamine the religious system which in essence does not support the realization of a democratic and pluralistic modern society in order to comply with the standard of international law and human rights.
\end{abstract}

Keywords: Islam, ethics of pluralism, human rights, international law.

\section{Introduction}

Pluralism is a modern phenomenon privileging individual freedom. Pluralism does not only emphasize diversity but also questions the monopoly of authority by people, groups or institutions in deciding ethical values. In this understanding, pluralism is not opposed to the idea of unity and universalism founded on rationalism and humanism. 
Indeed, pluralism intends to bring the values to the transnational and global level. This does not mean that pluralism discards local and religious values. Pluralism in fact obtains its legitimacy and acceptance from the justification of universal values into local context. So, the ethics of pluralism is a concept which constantly negotiates between local and universal ethical values. ${ }^{1}$

Islam does not recognize clerical institutions, as well as other institutions claiming to possess absolute authority on truth claim, or to represent views that monopolizes truth. Several moral tradition has existed for a long time, in which some that are more tolerant and open than others are suitable to use for today's world. ${ }^{2}$ Muslims learn how to relieve themselves of medieval Islamic ethics and treat the Qur'an as 'a complete ethical system' as part of an effort to elaborate novel principles on the participation of Muslims in the international community. ${ }^{3}$

\section{Freedom of Religion in Islam}

The political worldview adopted by al-Qaeda/bin Laden exhorts the unity of belief against the forces that suppress them, attributing the title of devil to the Christian and Jewish communities, and also to 'Muslims' considered siding with both groups to deviate the Muslim community from its purpose, which is the creation of a faithful world community. They deploy arguments based on the Qur'anic verses 9:5 and 5:44. The interpretation of these verses is highly contestable. Only a small number of people are inspired to follow up on the interpretation. Piscatori elaborates that the theology of the these small number of people has revived fundamentally the jihad ideology of Egyptian group who assassinated the President Anwar Sadat. ${ }^{4}$

\footnotetext{
${ }^{1}$ Muhammad Khalid Masud, "The Scope of Pluralism in Islamic Moral Tradition" in Sohail H. Hasmi (ed.), Islamic Political Ethics, Civil Society, Pluralism and Conflict (Oxford: The Princeton University Press, 2002), pp. 136-147.

2 Ibid.

${ }^{3}$ Ibid.

${ }^{4}$ Dale Eickelman, "Islam and Ethical Pluralism", in Sohail (ed.), Islamic, p. 116. This verse is related to the concept of jihad in Islam then used by the Western mass media as the theological foundation for the jihad movement in the modern era. This movement is categorized as terror movement and its members as terrorists. On the definition of terrorism see August Richard Norton "Terrorism" in John L. Esposito (ed.), The Oxford Encylopedia of the Modern Islamic World (New York: Oxford University Press, 1995), pp. 205-209.
} 
This minority radical understanding is not the real face of Islam. Robert Bellah argues that Islam in its earliest form at the seventh century according to the standard of the time was very modern in terms of commitment, involvement, and participation of ordinary people. The leadership position was open to anyone, as the values of revelation emphasized on equality among the faithful. ${ }^{5}$ Bellah also maintains that the discipline which maintained the early Muslim community to "exemplify perfectly" the principles of the Qur'an has brought modernity to the land of Muslims, as well as encouraged them to let go off their local and tribal attributes. ${ }^{6}$ Indeed, Bellah states that "the effort of modern Muslim to depict the early Muslim community as a prototype of nationalist project is a baseless and a-historical effort."

Even though there seems to be a conflict between the verse of "there is no compulsion in religion" and tradition (badith) of "harsh punishment against the apostates and those who break their covenant with the Prophet", the Qur'anic exegesis experts state that the harsh punishment is necessary to emphasize "the demands of moral foundations" such as fulfilling promise and contract as well as protecting the welfare and security of the Muslim society from aggressors. ${ }^{8}$ The message on the whole is "voluntary surrender to the will of God" driven by universal guidance contained in men's heart." Even the Qur'an encourages the Prophet Muhammad to be tolerant of his enemies (10:99). ${ }^{9}$

Using force to compel religion is forbidden as humans are deemed to be capable of and must be given freedom to differentiate and choose right from wrong. In other words, humans are deemed to be mature, in no need of compulsion, as God has given discerning ability

\footnotetext{
5 Robert N. Bellah, Beyond Belief: Essays on Religion in a Post-Traditional World (New York: Harper \& Row, 1970), pp. 150-151.

${ }^{6}$ Ibid, p. 160.

7 Ibid, p. 151.

${ }^{8}$ David Little, "The Development in the West of the Right to freedom of religion and Conscience: A Basis for Comparison with Islam," in David Little, John Kelsay and Abdul Aziz A. Sachedina (eds), Human Rights and the Conflict of Cultures: Western and Islamic Perspective on Religious Liberty (Columbia: University of South Carolina Press, 1988), p. 30.

${ }^{9}$ This is the argument of Abdulaziz Sachedina, "Freedom of Conscience and Religion in the Quran," in Little, Kelsay, and Sachedina, Human Rights, p. 68, and p. 74.
} 
to humans and no longer send any prophet after Muhammad to educate them on the truth. As the last prophet, Muhammad has set up the foundational principles of teaching which could be built upon through the ages. As such, it is up to humans to creatively capture the message in the main teachings of the last prophet and actualize them in daily life. ${ }^{10}$

Faith in God as the main principle of the teaching conveyed by the prophet Muhammad gives rise to moderate attitude and abhorrence of tyranny. Both of these attitudes in turn give rise to the principle of religious freedom such as the Prophet himself was reminded: "Verily if your God commands, all humans on earth would have faith. So would you (Muhammad) compel humans to all be of faith? (10:99). As such the principle of religious freedom is an honor for men from God, as God recognize humans' right to choose their own life path, that they bear fully the consequence of that choice. Experts have noted that the institutionalization of the principle of religious freedom first made by the prophet Muhammad after he migrated to the multireligious and multicultural Medina. Now the principle of religious freedom has been used as a social foundation of modern politics. ${ }^{11}$

More specifically Fazlur Rahman asserts that the Prophet "admitted without doubt that Abraham, Moses, Jesus and others are prophets like him." The different message they brought due to the difference of time and place is viewed as containing the same universal and identical essence (42:15), as the guidance of God is universal in nature and is not limited to one nation. The idea of "book" according to him is a generic term for the Qur'an which represents "the totality of revelation." 12

Pluralism is also driven by the fact that the boundaries of Muslim world was not as demarcated as now. Only in the end of the $16^{\text {th }}$ century the material and intellectual condition as a symbol of dualism between the West and East Islam was recognized. This has taken a permanent form in the seventeenth and eighteenth century, when the idea that the Muslim world is different from the European and

${ }_{10}$ Nurcholish Madjid, Pintu-pintu Menuju Tuban (Jakarta: Paramadina, 1995), pp. 218219.

11 Ibid.

12 Fazlur Rahman, Major Themes of the Quran (Minneapolis: Bibliotheca Islamica, 1980), pp. 163-164. 
Western world was formed. Even after this period the realization of 'the other' continues to exist among the elites and the common people of the majority of Muslims from Indonesia to Morocco.

Different from the Eastern world experience, religion according to the European experience is the number one enemy of democracy, pluralism, and egalitarianism. According to Helmut Schmidt, Western Europe desired to uphold democracy and pluralism by first eliminating the role of religion in politics. According to Nurcholish Madjid, different from Europe, the religion of Islam in Indonesia has had a positive role. However, the main stumbling block of this positive role in the social change for democracy and pluralism is faulty assumptions and suspicions. Stereotypical terms such as "extreme Islam (terrorist Islam)" and "Christian-Catholic conspiracy" have resulted in disastrous consequences in society and do not at all support positive change towards democracy and pluralism. It is the responsibility of religious leaders to reexamine traditional potentials of their religious system which in essence supports the realization of democratic and pluralistic modern society. ${ }^{13}$

The awareness of Muslims on the existence of others is not always neutral and tolerant but also not always intolerant. When the rulers of the Iberian Peninsula violated the treaty that they have agreed on religious freedom by driving away the Jews from Spain in 1492, while in Portugal they were obligated to adopt Christianity in 1497, most Jews sought refuge in Morocco and other African countries. Similarly, the King of Morocco, Muhammad V, protected the Jews by granting them Moroccan citizenship during the Second World War to prevent them from being deported by the French Vichy. The Jews of French citizenship did not obtain the same protection.

The principle of openness on differing interpretations of religious scripture in Muslim tradition and on other non-Muslim tradition precedes Modern Europe by a long time. In Andalusia, for example, Abu Ishaq Al-Shatibi (d. 1388) placed the human mind at the central means to understand Islamic law and interpret them in social, economic, and political context. ${ }^{14}$ This kind of formulation admitted the possibility of difference in interpretation. In India, Akbar who

${ }^{13}$ Nurcholish Madjid, Tradisi Islam: Peran dan Fungsinya dalam Pembangunan di Indonesia (Jakarta: Paramadina, 1997), pp. 135-138.

14 M. Khalid Mas'ud, Shatibi's Philosopby of Islamic law (Islamabad: Islamic Research Institute, 1995). 
presided over the victory of Islam also supported rah-i 'aql (reason), open dialogue and religious freedom. Akbar used reason to show himself as a ruler whose government is not based on a certain religious tradition. He purposefully created a kingdom in which a variety of religion could co-exist. He stated that "morality could be directed by a critical mind" and "we must not place reason beneath the dictates of religion." 15

The historical antecedent of tolerance and usage of reason to achieve it facilitate the understanding of Islam in history and how Muslims interpret, accommodate and explain difference in belief and religious conviction. Al-Shatibi and Akbar has showed that the trail of 'modernity' need not necessarily depend on replicating the European experience. Modern theory in the middle of twentieth century assumed that modernity's cultural project as built by Modern Europe and the institutional constellations which appeared there would take over all modernization process and modern society itself. ${ }^{16}$ Equivalent with this assumption is religion has no place in the domain of 'modern' public. In the words of the philosopher Richard Rorty, outside of the circles of the faithful, religion could only function as a "conversational stopper". ${ }^{17}$

Every discussion on tolerance and religion must involve three dimensions: tolerance among different traditions within a religion; tolerance between religion and tolerance of the religion itself. ${ }^{18}$ Several Muslim intellectuals today state that Islam has offered timeless precedent on "peace, harmony, hope, justice and tolerance, not only for Muslims but also for all of mankind," and tolerance is a problem only for people outside of Islam. ${ }^{19}$ The teachings of the Qur'an teaches shuratconsultation), which is the equivalent of democracy, progresses and develops from time to time towards perfection. Similar with the

${ }^{15}$ Amartya Sen, "East and West: The Reach of Reason," New York Review of Books, July 20 (2000), pp. 33.

16 S.N. Eisenstadt, “Multiple Modernities,” Daedalus 129:1 (Winter 2000), p. 1.

${ }_{17}$ Quoted in John Keane, "The Limits of Secularism," Times Literary Supplement, January 9 (1988): pp. 12-13.

18 M. Khalid Mas'ud, "Religions and Tolerance: Islam," paper presented at a symposium on "Religions and Tolerance," May 8-10, 2000 Postdam and Berlin, Germany, 2 (cited by Eickelman with permission).

${ }^{19}$ Syed Othman Alhabshi and Nik Mustapha Nik Hasan (eds), Introduction to Islam and Tolerance (Kuala Lumpur: Institute of Islamic Understanding Malaysia, 1994), pp. 1-2. 
experience of American democracy introduced by its founders, the principle of equality and right to speak are continuously being elaborated and fought for from time to time until now. ${ }^{20}$

Similarly, the concept of Islamic behavior is elaborated and expanded throughout ages. As put forward by Robert Wuthnow, all religion has problems of "articulation". When idea and practice do not articulate closely with social situation, "it seems like that they are considered by potential audience who formed the social setting as unrealistic, artificial, and too abstract." However, when they articulate it too closely with the local social condition, they would be considered as something esoteric, parochial, time-bound, and unable to attract a wider and more mature audience. ${ }^{21}$

Even when Muslim thinkers supported the separation of Islamic tradition from other tradition, due to European economic domination and colonializing history, they still support the elaboration of thought and action which could facilitate discovery of elements and actions that are new and fresh. Hence, a prominent thinker like Sayyid Qutb (19061966) writes of Islam as a system or program (minhaj), which is a system of thought and action which is clear and distinguishable from other non-religious system. For Qutb and other activists, it is not sufficient to profess Islam and follow Islamic practice. One has to reflect and articulate. When they have recognized that they are involved in the Islamization of their society, an objective method of thinking about religion appears clearly. These thoughts are reflected on popular level through new books on Islam, famous preachers' sermon, and books which proves the equality of science and the Qur'an. ${ }^{22}$

\section{Pluralism in Traditional Islam}

Traditionally, Islam has never been presented in a monolithic way. Since the beginning, Muslim history has been marked with a variety of approaches on morality related to source, method, and emphasis. Sometimes they are in opposition with each other, sometimes they continue existing theory and sometimes they complement each other.

\footnotetext{
${ }^{20}$ Sadek J. Sulaiman, "Democracy and Shura," in Charles Kurzman (ed.) Liberal Islam: A Source Book (New York: Oxford University Press, 1998), pp. 96-98.

${ }^{21}$ Robert Wuthnow, Communities of Discourse: Ideology and Social Structure in the Reformation, the Enligthment, and Europen Socialism (Cambridge: Harvard University Press, 1989), p. 3.

22 Yves Gonzalez-Quijano, Les gens du Livre: Edition et champ intellectual dans l'Egypte Republicane (Paris: CNRS Editions, 1998), pp. 171-98. Quoted by Eickelman, p. 123.
} 
Hadith literature for example show moral tradition is very important as reflection of the Prophet's, his companions', and their successors' behavior. These traditions develop a comprehensive ethical system of the Prophet's tradition. They often refer to pre-Islamic Arab tradition, especially when depicting the rejection and acceptance of the Prophet's Sunna. Sunna is defined not merely as the words and practice of the prophet, but also practices which were tolerated upon by the Prophet.

In the history of Islam Sunna is defined not only as all the activities performed by the Prophet Muhammad, but also activities performed by the al-Khulafa> al-Rastidur (Four Righteous Caliphs) and the traditions existing in Muslim society which were justified by Muslim legal experts who deemed those traditions as not against the clear boundary set by the Qur'an and the Prophet's Hadith. One of the madhhab (school of thought) which grew in the history of Muslim legal history is the Maliki attributed to Imam Malik as the Medinan scholar who constructed his figh through his book al-Muwaththa'. The legal theory built by Imam Malik placed the Qur'an as the first source of law and 'amal abl al-Madirab as the second source of law. The term Sunna given to Hadiths currently was introduced later as another set of source of Islamic legal theory by Malik's student al-Shafi'i. In essence, the term 'amal abl al-Madirah meant by Imam Malik refers to the traditions performed by the Prophet and his companions living in Medina. In later times the term 'amal abl al-Madirab became the standard used by the Maliki madhhab to judge the veracity of Hadiths in their version of Islamic legal study. ${ }^{23}$

One of the terms found in Islamic literature is adab, which could be a larger umbrella term than sunna to represent the breadth of Muslim moral tradition. Adab depicts the values of the Arab tribes such as manliness, honor, resilience and tolerance. Adab is a tradition which represents a humanist approach on morality, as written by Ibnu Muqaffa (d.756) and Ibn Qutayba on this subject. Their writing covers the behaviors of the leaders and the led as well as principles related to these behaviors. Their writing is more comprehensive than Hadith books, as they utilized a variety of sources, such as the pre-Islamic Arab tradition, Persian literature, the Qur'an, Islamic history, ancient Persian history, Greek and Indian literature. Ibnu Muqaffa for

23 On discussion on sunna see Joseph Schacht, An Introduction to Islamic Law (Oxford: Clarendon Press, 1964). 
example, translated Kalila wa dimna, a book on moral story originating from India, as well as ethical literature which provides ethical codes of a variety of professions including musician. ${ }^{24}$

The sufi has a different method of life and implementation of spiritual practices (tasqwwnf). Different experiences of getting oneself closer to God make the practice of tas dwwn more diverse. Because the aim of the sufi is to be as close as possible to God to the point of unity, they must pass through several spiritual levels known as maqamat..$^{14}$ Among common levels (maqamat) are repentance (tawbat), detachment (zubd), patience (sqbr), perseverance (tawakkal) and contentment (ridha). Above these levels are al-mabdbbah (love), alma'rifah (knowledge), al-fanas and al-baqas (desctruction and construction) and ittih $d \notin$ (unity).

The concept of al-ma'rifah was first formulated by Dhu al- Nun alMisri (d. $214 \mathrm{H})$. According to al-Misri ma'rifah is different for everyone. Ma'rifah on the oneness of God possessed by the layperson is founded on taqlit (blind imitation), while the more superior ma'rifah is based on proofs. While ma'rifah for the sufi or friends of God is based on kashf and mushaAadah. According to Dhu al-Nun al-Misri, the true ma'rifah of God would illuminate the heart brightly and clearly, making one always close to God until he or she is annihilated within His oneness. In such condition, people talk based on His knowledge and see with His eyes, as well as act with His action.

Kalam (theology) is an Islamic tradition fertile with debates in the second and third Islamic century. There are a wide variety of opinions on topics such as the attribute of God and the scope of reason. It covers questions as to whether or not good and bad can only be known by revelation and religion; Could human reason also discern good and bad? The kalam literature is replete with various schools of thought with diverging opinions yet still respectful of each other's authority.

One famous school in Islamic theology is Khawarij, started with political motive which broadened to cover religious ground on the

\footnotetext{
${ }^{24}$ Barbara D. Metcalf, (ed.), Moral Conduct and Authority: The Place of Adab in South Asian Islam (Berkeley and Los Angeles: University of California Press, 1984); Brian Silver, "The Adab of Musicians," pp. 315-29.

${ }^{14}$ Harun Nasution, Islam Ditinjau Dari Beberapa Aspeknya (Jakarta: UI Press, 1986), p. 78.
} 
issues of sama' reason (which means whether goodness or badness could be determined by shara' or could it be determined by reason) in addition to the issue of big sin (al-kaba $\left.x_{n}\right)$. Those with problems, such as in the case of tabsim, not basing decision on God's law as contained in the Qur'an, would be branded as unbeliever (kafor) by the Khawarij. The categorization of the term kafer in the end causes division among the Khawarij to become 18 sects. However, historically, only some became big enough which is deemed to represent the smaller sub-sects. Among them are Azariqah, al-Najdah, al-Ajaridah, al-Sufriyah and al'Tbađtiyah.

Like Khawarij, the Murji'ah sect was born out of political reason, specifically the divisive issue of khilafah and related religious stances taken by the Khawarij. Mu'tazilah adopted this line of reasoning in the beginning, problematising the issue of serious sinner (murtakib alkaba刘). After being involved with philosophy, the Mu'tazilah debated on the issues of divinehood, qadar, good and bad, God's nature, and human action which were all discussed through reason philosophically. Among the leading figure is Washil ibn Atha'. In their school of thought the Mu'tazilah held on to five basic teachings (al-usilbalkhamsab). Al-Ash'ariyah is a theological school of thought founded by Abu Hasan al-'Ash'ari, one of the the divisons of Sunni Islam ( $\mathrm{Abl}$ alSunnab wa al-Jamazh). The teaching Al-'Ash'ariyah refuted a lot of Mu'tazilah's opinions. He based his statement on the Qur'an and Hadith. In his theological thought, he attempted to purify God from attributes unfit for God. God's power is absolute and unlimited. Among the Ash'ariyah intellectuals was al-Ghazali who in the end used tashwnuf or sufistic approach. Maturidiyah was founded by al-Maturidi. As a thinker in opposition to Mu'tazilah and a defender of Ahl alSunnah, al-Maturidi used a lot of athar(sound traditions). Some of his thoughts are compatible with al-'Ash'ariyah and some are compatible with Mu'tazilah.

With regards to figh, even though it is almost equivalent to positive law in Western style, figh in general is treated as a tradition which creates moral responsibility instead of legal regulations. Snouck Hurgronje even defined Islamic law as a doctrine of ethics and responsibility. ${ }^{25}$ Whether fiqh is purely legal regulation or moral

25 Snouck Hurgronje, Selected Works of C. Snouck Hurgronje, ed. G.H. Bousqet and Joseph Schacht (Leiden: E.J. Brill, 1957), p. 256. 
tradition, what is important is figh has depicted since the beginning of the existence of a variety of interpretations. Figh in the beginning developed as a multiple local legal tradition. The plurality of opinion in fiqh is something proverbial. Figh is understood as shariah which in history has formed about 9 madhhabs (school of thought) with equal position. This diversity has often been symbolized as a blessing. Ijtihad is the trigger of differences in understanding, as it is highly encouraged even though the result is not accurate it is still bestowed with spiritual reward. As such, diversity is a common thing in Islamic legal tradition. In Islamic history several madhhabs are known as a reflection of plurality in Islam, be it from the Sunni or Shi'i group.

Madhbab linguistically means "the way to go". In books on Islam, the term madhhab is closely related with Islamic law, with four famous madhbabs in the Sunni tradition which are the Hanafi, Maliki, Shafi'i, and Hanbali madhhabs. These are only several madhhabs in Islam and they are now the representation of Sunni madhhabs, as from the first century until the beginning of the fourth century there has not been fewer than nineteen legal madhbabs which means that the early Muslims did not stop to modify the laws to suit the evolving civilization. ${ }^{26}$ The appearance of these madhhabs were due to several factors: difference in understanding the text of the Qur'an; difference in understanding tradition (Hadith); difference in understanding the method of text linguistic interpretation; difference in qiyas (analogy); difference in usage of legal verses; difference in preferring a particular opinion; difference in understanding legal cause ('illat); difference in understanding naskb (abrogation). ${ }^{27}$

It is noteworthy that the early Muslim caliphs were concerned that the variety of legal opinions would result in a variety of justice being exempted. They attempted to unify the legal opinions, but the jurists rejected these attempts. They were worried that the caliphs' attempt would cause the state to meddle too much into religious affairs and their freedom of thought would be disturbed. They left the implementation of the law to the state, but they never agreed to codify

\footnotetext{
${ }^{26}$ Said Ramadan al-Buty, Islamic Law its Scope and Equity (Jakarta: Gaya Media Pratama, 1996), p. 66.

${ }_{27}$ M. Ali As-Sais and Mahmud Syaltut, Perbandingan Mą̧hab dalam Masalah Fiqh, trans. Ismuha (Jakarta: Bulan Bintang, 1987), pp. 16-18.
} 
their opinions into state law. What was even more unique in an Islamic state, the law of other religion was still applied to their believers. ${ }^{28}$

The above description shows that Muslim society has always been used to pluralism: be it in the area of spirituality, theology, or law. Lately there has also been complaints and never ending unsuccessful effort to unify opinions in the Muslim world. Some modern Islamic law observers generally treated this phenomenon of pluralism as a deviation from the ideal. Among Western scholars such as Reuben Levy, George-Henri Bousquet and Joseph Schacht, pluralism is defined in theoretical and practical terms. The ideal theory is derived from the Qur'an, Sunna, and figh. The custom ('urf) practiced by Muslims were treated as deviation. However, according to Mas'ud, this dichotomy is more imaginary than real, as both continues to adapt to each other. The universal principle which determines the range of acceptable pluralism is being continuously defined with reference to local objectification. ${ }^{29}$

A different intellectual tendency when understanding the Shari'ah could end up to a variety of understanding with regards to general principles contained in Shariah. This variety of understanding which causes the emergence of a variety of figh madhhabs, Islamic theology and philosophy is the perfect example showing Islamic teaching could be interpreted in various ways. The multi interpretative nature of Shariah is a foundation for Muslim flexibility in history. Furthermore, this shows the existence of pluralism in Islam. As such Islam cannot and should be viewed as monolithic. This means that the different understanding of Muslims on their religion is due to differences in their social, economic, and political context. ${ }^{30}$

\section{The Challenges of Modern Period}

Only in the early nineteenth century as a result of contact with Western countries, the role of the state in Islamic societies underwent

\footnotetext{
28 Shihab al-Din al-Qarafi elaborates very well the relationship between government and law. To alQarafi, the state or government is not more than a group in society which must attempt to defeat its rival such that enough force could be gathered to impose a small instruction to another unit of group in the society. Abd al-Fatah Abu Ghuddah (ed.), Kitab al-Ihkeam fi Tamyiz alfatawa wa tasarruf alqadi wa al-Imam (Aleppo: Maktabat al-Mabuat al-Islamiyah, 1387/1967).

${ }^{29}$ Mas'ud, Pluralism, p. 141.

30 Bakhtiar Effendy, Teologi Baru Politik Islam, Pertautan Agama, Negara dan Demokrasi (Yogyakarta: Galang Press, 2001), p. 114.
} 
changes. The state involved itself in legal determination and regulations in society. This is possible as the concept of the state has undergone changes. The modern concept of the state is nation-state, which implied a policy of identity and unity. State in current times always put forward the agenda of reformation and also more directed in its functions and operations.

The modern political system always introduces practices which have never existed previously. As a result, there is always tension between past concept and current reality. A new paradigm is needed to understand the ethics of pluralism in Muslim society. In the past, the ethics of pluralism is more prominent as the society is more dominant than the state. Now in the modern era, the state plays a very dominant role such that there is only a little room for society to enjoy pluralism. As a result, modern Muslim society is not used to the ethics of pluralism. They are used to see issues in black and white, right or wrong. More worrying is the behavior of self-indulgence, the phenomenon of selecting person and group who claims to have the most true opinion and those outside their circle to hold false opinion and thus unworthy of life in this world.

An example often occurring in Muslim countries is the imposition of certain Muslims on certain government authority in the form of opposition to government's existence or forcing the government to follow their wishes. In several cases, groups or radical Muslims often force the government to adhere to their principles formulated by the organizations they founded. When the government refuses, they would accuse the government as un-Islamic and thus deserves to be fought against. In many cases, they act unilaterally to implement the version of Islam they uphold in societal life, causing opposition from other groups who uphold different versions of Islam. On the other hand, conservative ulama attempt to maintain their version of Islam using the government. Through the variety of fatwas they issue which implementations are often requested to the government, they issue the prohibition on the existence of certain groups which according to them does not fit the mainstream versions of Islam.

The above phenomenon describes clearly that the ethics of pluralism in Islamic history has undergone ebbs and flows as a result of changes that occurred in society. It seems that early Muslim society has shown more pluralism ethics than current Muslim society. One of the excesses experienced by Muslims as a result of dominant state role 
in today's modern era is the appearance of strain in the relationship between states in an international context. It is not a strange phenomenon when two or more states involved in great conflict, the citizens of the states often sit together around a table, exchanging opinions in peace. Or it could be found that people from the same country possessed very different opinion on certain states.

What is most risky in the modern era is the appearance of Muslim radical movements outside the legitimate Muslim government which claim to have implemented the true concept of political Islam. Their movements are outside the control of government and they attack the interest of states they deem to be against Muslims' interest. In Islamic legal system, these kinds of action are prohibited, as no one or no group could execute law. Only the state has the responsibility for this.

It seems that in the era of modernism or post-modernism, the idea of pluralism ethics has jumped from a traditional Islamic concept which emphasizes individual and society to a modern concept which emphasizes the relationship on a Muslim to a non-Muslim state. These aspects need to be developed seriously as in its history Islamic tradition does not provide a large room for the state to act as legal subject. There are at least two reasons why pluralism is known in Islamic concept. First, because it is compatible to human reason. The Qur'an for example emphasizes the importance of human reason and responsibility. Becoming a Muslim is a rational and responsible choice. Secondly, the foundation of pluralism is the acceptance of Islamic values as understood by a variety of people and community.

To position these two foundations in the context of the state requires a serious and deep thought. In Islamic literature, the state does not get serious attention as the concept of the state in Islam is simiar to a vehicle. Its function is to execute, not create law. Law precedes the state, not the other way around. As such, it is the responsibility of the Muslim political thinker to think about creating the theory of state in Islam, not only by citing from the past, but also by adapting the theory to the present modern era, which is very different from the past. The concept of state which covers legislative, executive, and judicative branches certainly requires a strong foundation to make Muslims believe that they could trust the state which has been founded by their elites. 


\section{A Case for Indonesian Muslim}

Indonesia as a Muslim majority country does not make Islam, but Pancasila, as the foundation of the state. However, Pancasila also faces the same problem in the issues of relationship of the state and religion and the relationship between religions. Muslim thinkers such as Nurcholish Madjid, Abdurrahman Wahid, Komaruddin Hidayat, Bakhtiar Effendy and Fachry Ali, are a few names among the many Indonesian Muslim thinkers who have attempted to build the concept of the relationship between the state and Islam to build an awareness of pluralism among religious societies to develop a strong and successful Indonesia at the international level.

The diversity of society is a unique feature of Indonesians which is not only represented by the diversity of race, language or religion but also the diversity of opinions which often influence the state constructs. Difference in opinion indeed possesses a positive influence in the development of society. However, an awareness of ethics and rules of engagement should be realized, that every member of society has the right to state their opinion freely and the responsibility to listen to the opinion of others respectfully. As such, humility to see the wrong within and the right does not need to be cultivated. To cite the opinion of Abu Hanifah, "our opinion is correct but could be incorrect and other's opinion is incorrect but could be correct". Nurcholish Madjid emphasizes the necessity of awareness of plurality. To Madjid, the Indonesian founding fathers had wisely agreed on the underlying principle of "Bhinneka Tunggal Ika" which is "pluralism". ${ }^{31}$

As such, Madjid stated further that the effort to manage differences in a democratic society requires a 'compromise' between contending parties, in the spirit of giving and receiving opinions. This means, no one or no group could act in an absolutist manner to implement the idea that they claim as true. They must learn to accept that no one is perfect. The attitude of "all-or-nothing" is against democracy. The phenomenon of "tug-and-pull" in society due to difference in opinion usually creates a majority and minority group. As such, the ethics of consultation in order to exchange opinion for the common good should be cultivated, eliminating the intention of defeating any particular group based on prejudice, fear, or mere desire

${ }^{31}$ Elza Peldi Taher (ed.), Demokratisasi Politik, Budaya dan Ekonomi, Pengalaman Indonesia Masa Orde Baru (Jakarta: Yayasan Wakaf Paramadina, 1994), p. 216. 
to triumph. It must be believed that through the ethics of consultation and opinion exchange, a social order could be realized and maintained.

Islam did not command justice only for Muslims but for mankind generally, and this is perfectly clear in the Qur'an, where justice is an obligation that must be observed even when one is dealing with enemy. In this context, Ghannoushi observes that Islam's basic commitment to equality is not at all in doubt either generally or in respect of the rights and obligations of non-Muslims. There are, however, differences of detail among jurist concerning the status of non-Muslims, which have largely been due to differences of religious belief and it is not unreasonable that some of these should be accepted. To attempt to establish total equality among people who subscribe to different values, might amount to injustice. To impose on non-Muslims, in other words, something that is disagreeable to their religions is likely to go against the essence of equality and justice. ${ }^{32}$

It is safe to note that nationality and religion are now separate matters, and are treated as such under the prevailing laws of contemporary Muslim states. People belonging to different religion enjoy equal rights, just as they also share equally in the duties of military service and taxation. It would be quite reasonable to depart from the earlier criteria of religion-based distinctions, and treat the issue from the wider perspective of equality and justice. ${ }^{33}$

There are two types of fraternity in Islam, namely the fraternity of man and religious fraternity, both of which are recognized in the Qur'an. That the believers are brethren (Q.49:10) is a clear and unequivocal affirmation of the religious fraternity of Muslims. He then adds that this level of fraternity of Muslims is not in conflict with the wider fraternity of man, and the two should in fact be seen as complementary, and not contradictory, to one another. ${ }^{34}$

However the vast majority of Muslims in Indonesia have difficulty to accept the reality of pluralism in the life of the state mainly related to the social and political life. Some of the points below indicate the level of difficulty for being in direct conflict with religious holy texts.

32 Rashid al-Ghanoushi, Huquq al-Muwatanah: Huqud ghayr al-Muslim fi-l Mujtama' alislami, $2^{\text {nd }}$ edn. (Herdon, VA: International Institute of Islamic Thought, 1993), p.48.

${ }^{33}$ Muhammad Salam Madkur, Ma'alim al-Dawlah al-Islamiyah (Maktabat al-Falah, 1983), 104.

${ }^{34}$ Yusuf al-Qaradawi, Al-Khasa'is al-Ammah lil-Islam (Cairo: Maktabat Wahbah, 1989), p. 84. 
In Indonesia the concept of equality between citizens is guaranteed in the Pancasila and the Constitution UUD 45. Not all religions are recognized in this country. There are six religions recognized by the Government of Islam, Catholicism, Protestant, Buddhist, Hindu and Kong $\mathrm{Hu}$ Chu. However, unlike Malaysia in which Islam is taken as the official religion of the State, Indonesian treats Islam equivalent to the other five religions and put them under the ministry of religious affairs.

The stipulation of this national policy has been in challenge among Muslims in Indonesia especially influential Islamist leaders who are always quoting some verses of the Qur'an and hadith and preaching them textually on the glory and the highest position of Muslims over other religious groups. Some cases reflecting the difficulties of Muslims in accepting political pluralism in social life are as follows:

\section{Leadership of non-Muslims}

An understanding that all religious groups are living in equality seems to be socially acceptable except when it is articulated in practical politics. Almost in every presidential election and regional elections as well as legislative elections the issue of Muslim superiority over nonMuslims candidates is sound in the context of how to elect a member of the legislative elections, local elections and reach its peak in the Presidential Election. Muslim preachers are often to quote some verses of the Qur'anic verses that forbid Muslims to choose a leader among non-Muslims. As a consequent, Muslims risk their lives in conflict when they are trying to articulate their political choices. Even MUI a few days before the general elections June 7, 1999 issued a fatwa calling on Muslims in Indonesia to choose one of the political parties who nominate the legislative candidates who are Muslims. This means that Muslims are urged not to choose a political party that all or most of the prospective members of legislative are non-Muslims.

Nevertheless MUI did not mention its statement as a fatwa but tawsifyah (opinion). Nonetheless, the public reaction was quite loud. Abdurrahman Wahid for example assesses that MUI has been overwhelmingly in political meddling. Even PDIP assesses MUI has indicated in sedition and violating Article 151 of the Criminal Code. This type of tawsizjah still has been used repeatedly in each General Election both in the legislative and executive elections. There are opinions that forbid Muslims to vote nationalist parties such as Golkar, PDIP, Democrat, and Nasdem. Even PAN, PKS and PKB were 
sprayed this ideology on the grounds they had been turned into a party that is open to all faiths. PPP is the only Islamic party who introduce a motto as a large house Muslims trying to take advantage of these ideologies and they succeeded in reaching Parliamentary threshold despite not getting into the top five.

The same ideology but softer is the emergence of opinion that "it does not matter to elect any party as long as their candidate of legislative members are Muslims". This opinion is more moderate but still reflects the difficulties of Muslims in accepting equality of all citizens despite religious differences. This negative campaign has been used even by the legislators of the nationalist parties to promote themselves in the legislative election campaign.

In the regional and provincial elections of major or governor the issue of Muslim superiority over non-Muslim candidate is noticeably sharper. The issue is then transformed into a lethal weapon that cut chances of non-Muslim candidates to win the election in the constituency areas with the majority of Muslims. A maneuver performed by the non-Muslim candidates is that they then see the opportunities to become a deputy. This technique works because then we watched this variant appears in Muslims and non-Muslims as the head and deputy head of the regional area. In North Sumatra, for example, the governor and his deputy T. Rizal Nurdin and Rudolph Pardede are of this type. When the governor died from a plane crash of the Mandala airline, Rudolph Pardede as the deputy replaced him as the governor. Though, the fact remains reluctantly accepted by the North Sumatera Muslim population along with the issue that the plane crash was set up by certain people to create opportunities for nonMuslims to became a governor, although the issue is not validated at all.

However, an alert of the possible rise of non-Muslims as a number one leader by process of replacement bring about vigilance for Muslims in Medan city not to win a combination of Muslim and nonMuslim candidates especially non-Muslims-Muslims. This is seen for example in the election of the mayor field when Sofyan Tan a Chinese Christian paired with Nelly Armayanti a Minang Muslim and Effendy Simbolon a non-Muslim and Abdi Jumiran a Javanese Muslim in Sumatra provincial election. Both failed to win the election for major of Medan and governor of North Sumatra. It is seen from a systematic 
effort made by the guard of mosques who urged his congregation not to choose the non-Muslims as the head of the region.

Presidential elections show the level of difficulty of the hard-line Islamic leaders in receiving Joko Widodo as a candidate who subsequently affects the understanding of Muslims in the matter of who should be president in this country. Ironically, though Joko Widodo and Jusuf Kalla are two Muslims but because of the party nominates them is PDIP which is connoted as a Christian-supported party, this pair was still rejected as candidates representing the Muslim community. Finally, the majority of parties that oppose the nomination of the two of them gave full support to Prabowo as a candidate who is considered to represent the interests of Muslims even though he comes from Gerindra party but supported by coalition of Islamic parties that supported by the Ulama. This effort nearly succeeded because Prabowo votes soared nearly and almost pass over the electability of Joko Widodo. The result shows that Joko Widodo won only 8 million votes over Prabowo.

Basuki Cahaya Purnama (Ahok) phenomenon as the governor of Jakarta to replace Joko Widodo who run for presidential election is an obvious example of the level of difficulty for Indonesian Muslims in adapting the discourse of equality among citizens. Since the beginning when Joko Widodo paired with Ahok as a governor and deputy governor candidates raise an issue that Ahok as a Chinese Christians do not deserve to be a leader in the city. The reason may also be used to deter Joko Widodo to become President because it will make Ahok as a governor of Jakarta. Likewise, it seems that democracy in Indonesia has surpassed the religion so that Joko Widodo was still elected as President and Ahok became Governor of Jakarta. Until recently, claims and objections against Ahok as a governor of Jakarta still echoed. This illustrates the low level of Muslims acceptance towards the equality among citizen regardless of their religion.

\section{Marriage with non-Muslim}

Marriage and family institutions are very strong traditions of Islam that cannot be neglected except for valid necessities. Islamic law does not promote celibacy and also generally prohibits sexual relations outside wedlock. The Prophet is reported to have said that marriage is part of his Tradition which should not be neglected. Esposito has thus pointed out that Islam considers marriage, which is an important safeguard for chastity, to be incumbent on every Muslim man and 
woman unless they are physically or financially unable to lead conjugal life. ${ }^{35}$

Muslim jurists therefore tend to protect the family institution resolutely and are cautious in accommodating any norms that would tend to disrupt that tradition of Islam. To urge to protect the family institution while guaranteeing equality of the spouses is not peculiar to Islamic law. Based on the Qur'an 2:221 and 60:10 there is consensus among both Sunni and Shi'a jurists that a Muslim woman is prohibited under Islamic law from marrying any non-Muslim man. Conversely, the Qur'an 5:5 permits Muslim men to marry 'women of the people of the book' (Christian and Jewish women). In the context of international law and human rights this will be considered discriminatory against women.

Muslim jurists have advanced some justifications for this provision under Islamic law. The foremost among those is that, under Islamic law a Muslim man who marries a Christian or Jewish woman has a religious obligation to honour and respect both Christianity and Judaism. Thus the woman's religious beliefs and rights are not in jeopardy through the marriage, because she must be free to maintain and practice her religion as a Christian or Jew. Conversely, a Christian or Jewish man who marries a Muslim woman is not under such obligation within his own faith, so allowing a Muslim woman to marry a Christian or a Jewish man may expose her religious beliefs and rights onto jeopardy. This justification is therefore hinged mainly on wanting to protect the religious beliefs and rights of Muslim women. AlQaradawi has thus argued that:

...While Islam guarantees freedom of belief and practice to the Christian or Jewish wife of a Muslim, safeguarding her rights according to her own faith, other religions, such as Judaism and Christianity, do not guarantee the wife of a different faith freedom of belief and practice, nor do they safeguard her rights. Since this is the case, how can Islam take chances on the future of its daughters by giving them into the hands of people who neither honor their religion nor are concerned to protect their rights?" 36

35 J. L. Esposito, Women in Muslim Family Law (Syracuse: Syracuse University Press, 1982), 15.

36 Yusuf al-Qaradawi, The Lanful and the Prohibited in Islam (Kuwait: International Islamic Federation of Students Organisations: 1984), pp. 184-186. 
On the basis of guaranteeing the freedom of thought, conscience, and religion under international law and human rights, it could be argued that other religions, such as Judaism and Christianity, would now also under an international obligation to guarantee the freedom of belief and religion to a Muslim wife and thus safeguarding her rights according to her own faith. If so, will this remove the prohibition of Muslim women from marrying men of the people of the book? Abd. Al-'Ati has observed that the honor and reverence that the Muslim must give to the faith of his Christian or Jewish counterpart is an integral part of the Islamic faith while the same 'reciprocity' is not an integral part of either the Christian or Jewish faith. The required unreserved honor and reverence is a matter of faith that cannot be imposed by law. For the same reason the Muslim male is prohibited in Islamic law from marrying an idolatress because of the psychological factors involved. Faith is the most private aspect in the relationship between man and God. It cannot be imposed or conferred; nor it is the question of discrimination between men and women in Islam. ${ }^{37}$

However, the juristic view of some contemporary Muslim jurists is that since Muslim women are prohibited completely from marrying non-Muslim men, the Muslim men would also be temporarily prohibited from marrying women of the people of the book' in a situation where there is apprehension of a high number of Muslim women remaining unmarried, until the situation is remedied. This is based on the doctrine of public welfare (maslah dh) under Islamic law. ${ }^{38}$ This opinion is still adopted in the Indonesian Muslim community, the traditional ulama of the Muhammadiyah and NU together with other hard-line Islamic groups such as FPI, PUI and HTI who balked at the plan laws that will permit interfaith marriage both Muslim men with non-Muslim women or vice versa.

There is an attempt made by the Assessment Team Compilation of Islamic Law of PUG Religious Affairs in the form of "Counter Legal Draft" one of which is the design of interfaith marriage by recognizing the existence of the marriage, and protect the settings. Prominent figures who support CLD include Musdah Mulia, Abdul Muqsith and Ulil Abdallah. Ulil said that the prohibition of interfaith marriage is

37 H. Abd Al'Ati, The Family Structure in Islam (Indianapolis: American Trust Publications, 1977), p. 143

${ }^{38}$ Qardawi, The Lawful, 184. 
contextual. At the time of the Prophet motivation to ban the interfaith marriage was more influenced by the condition of the people who are still few, weak and are trying to expand and strengthen the community, otherwise Muslims will be exhausted by non-Muslims. At present time the number of people already one more billion; why then should be afraid of marriage with non-Muslims? At that time Islam has made progress by allowing Muslim men married to women from the people of book, the Jewish and Christian. Interfaith marriage, he argued, is not a theological issue but social one.

This proposal has received serious challenges from the participants who were invited to respond to this CLD. Tahir Azhary, Hasanuddin AF, K.H. Husein Muhammad, Irfan S. Awwas of MMI who stated that KHI Draft of the Ministry of Religious Affairs (MoRA) version rejects the Shari'a. Therefore, they agreed to rejecting the permissibility of marriage with non-Muslims. ${ }^{39}$

\section{The establishment of non-Muslim Houses of Worship}

In Indonesia, freedom of religion is a very sensitive issue. For Indonesian Muslims missionaries issue is a common enemy that must be dealt with very seriously. SKB3 Menteri (Joint Decree of three Ministries) on the establishment of houses of worship is used as a weapon to reject the establishment of the church in some places inhabited by predominantly Muslim community.

A study on Religious life profiling the majority and minority in North Sumatera for example, has identified a potential conflict along with religious life in this area. This profile can certainly represent what is going on in Indonesia as a whole: a) The establishment house of worship that does not comply with the legislation in force; $b$ ) The Call for a new religion to people who already subscribe to a particular religion with material rewards. It is happening in remote areas very often; c) The group that secretly has been pitting communities with flyers of SARA; d) Personal disputes, group, organization that eventually evolved into a religious conflict; e) Use of houses as places of community religious worship.

Issues related to the establishment of houses of worship have turned into complex issues in this area. It begins with the conceptual differences between Islam and Christianity. For Muslims despite

39 Pagar, Perkawinan Beda Agama Wacana dan Pemikiran bukum Islam di Indonesia (Bandung: Citapustaka Media, 2006). 
coming from different members of the organization they are still allowed and justified to worship together in any mosque, without noticing differences in the organization. So the motivation to construct another mosque lays on the issue of capacity. By contrast, among the Christian circles, it is not allowed for one sect to worship in a church unless it complies theologically with the congregation membership. Then every sect must have each church, so that the church building grows significantly church that often trigger the reaction of Muslims who are not pleased with the growth of the church in their neighborhood. ${ }^{40}$ There is an impression in harmony dialogue that for Muslims, Christians being offensive with their proposal on the establishment of houses of worship, while among Christians Muslims suffer from inferiority complex. Therefore any discussion of the issue of the establishment of houses of worship is quite long, and takes a lot of energy.

\section{Conclusion}

Pluralism requires Muslims to adapt to the existing social reality. In this context it is an arduous task for Muslim thinkers to review the doctrine of the old legal doctrine that is not in line with the reality of modern life. Muslims now live in the nation state that does not distinguish its population by religion category but to treat them as one nation, one national language. Every citizen is treated equally before the law. Consequently, Islam is treated the same as other religions. So as to the national law is also applicable to all citizens regardless of their religion. In this regard, Islamic law can only be enforced if it has been used as a national law. The reality is that it is still difficult to be accepted by the majority of Muslims in Indonesia so that it often leads to social conflict due to lack of awareness of pluralism in the life of nation. []

\section{References}

\section{Books and Articles}

Abd Al'Ati, H. The Family Structure in Islam. Indianapolis: American Trust Publications, 1977.

\footnotetext{
${ }^{40}$ Research Report, Profil Kebidupan Beragama Mayoritas dan Minoritas di Sumatera Utara, (Lembaga Penelitian IAIN Sumatera Utara, Unpublished research report, 2012).
} 
al-Buty, Said Ramadan. Islamic Law its Scope and Equity. Jakarta: Gaya Media Pratama, 1996.

al-Ghanoushi, Rashid. Huquq al-Muwatanah: Huqud ghayr al-Muslim fi-l Mujtama' al-islami, $2^{\text {nd }}$ edn.. Herdon,VA: International Institute of Islamic Thought, 1993.

Alhabshi, Syed Othman and Nik Mustapha Nik Hasan (eds). Introduction to Islam and Tolerance. Kuala Lumpur: Institute of Islamic Understanding Malaysia, 1994.

al-Qaradawi, Yusuf. Al-Khasa'is al-Ammah lil-Islam Cairo: Maktabat Wahbah, 1989.

al-Qarafi, Shihab al-Din. Kitab al-Ihkam fi Tamyiz alfatawa wa tasarruf alqadi wa al-Imam, ed. Abd al-Fatah Abu Ghuddah. Aleppo: Maktabat al-Mabuat al-Islamiyah, 1387/1967.

As-Sais, M. Ali and Mahmud Syaltut. Perbandingan Marhab dalam Masalah Fiqh, trans. Ismuha. Jakarta: Bulan Bintang, 1987.

Bellah, Robert N. Beyond Belief: Essays on Religion in a Post-Traditional World. New York: Harper \& Row, 1970.

Effendy, Bakhtiar. Teologi Baru Politik Islam, Pertautan Agama, Negara dan Demokrasi. Yogyakarta: Galang Press, 2001.

Eisenstadt, S.N. “Multiple Modernities.” Daedalus. 129:1 Winter 2000.

Elza, Peldi Taher (ed.). Demokratisasi Politik, Budaya, dan Ekonomi: Pengalaman Indonesia masa Orde Baru. Jakarta: Yayasan Wakaf Paramadina, 1994.

Esposito, J. L. Women in Muslim Family Law. Syracuse: Syracuse University Press, 1982.

Harian Repulika. Jakarta, 7 June 1999.

Hurgronje, C. Snouck. Selected Works of C. Snouck Hurgronje. ed. G.H. Bousqet and Joseph Schacht. Leiden: E.J. Brill, 1957.

Jateng Pos, Jawa Tengah, 4 June 1999.

Keane, John. "The Limits of Secularism." Times Literary Supplement, January 9, 1988.

Laporan Penelitian, "Profil Kehidupan Beragama Mayoritas dan Minoritas Di Sumatera Utara." Lembaga Penelitian IAIN Sumatera Utara, Unpublished research report, 2012. 
Little, David. "The Development in the West of the Right to freedom of religion and Conscience: A Basis for Comparison with Islam." in Human Rights and the Conflict of Cultures: Western and Islamic Perspective on Religious Liberty. ed. David Little, John Kelsay and Abdul Aziz A. Sachedina. Columbia: University of South Carolina Press, 1988.

Madjid, Nurcholish. Pintu-pintu Menuju Tuban. Jakarta: Paramadina, 1995.

-. Tradisi Islam: Peran dan Fungsinya dalam Pembangunan di Indonesia. Jakarta: Paramadina, 1997.

Madkur, Muhammad Salam. Ma'alim al-Dawlah al-Islamiyah. Maktabat al-Falah, 1983.

Mas'ud M. Khalid. Shatibi's Philosophy of Islamic Law. Islamabad: Islamic Research Institute, 1995.

. "Religions and Tolerance: Islam." paper presented at a symposium on "Religions and Tolerance." May 8-10, 2000 Postdam and Berlin, Germany.

. "The Scope of Pluralism in Islamic Moral Tradition." in Islamic Political Ethics, Civil Society, Pluralism and Conflict. ed. Sohail H. Hasmi. Oxford: The Princeton University Press, 2002.

Metcalf, Barbara D (ed.). Moral Conduct and Authority: The Place of Adab in South Asian Islam. Berkeley and Los Angeles: University of California Press, 1984.

Nasution, Harun. Islam Ditinjau Dari Beberapa Aspeknya. Jakarta: UI Press, 1986.

Norton, August Richard. "Terrorism." in John L. Esposito (ed.). The Oxford Encylopedia of the Modern Islamic World. New York: Oxford University Press.

Pagar. Perkawinan Beda Agama Wacana dan Pemikiran bukum Islam di Indonesia. Bandung: Citapustaka Media, 2006.

Qaradawi, Yusuf al. The lawful and the Probibited in Islam. Kuwait: International Islamic Federation of Students Organisations, 1984.

Rahman, Fazlur. Major Themes of the Quran. Minneapolis: Bibliotheca Islamica, 1980. 
Schacht, Joseph. An Introduction to Islamic Law. Oxford: Clarendon Press, 1964.

Sen, Amartya. "East and West: The Reach of Reason." New York Review of Books. July 20, 2000.

Sulaiman, Sadek J. "Democracy and Shura." in Liberal Islam: A Source Book, ed. Charles Kurzman. New York: Oxford University Press, 1998.

Wuthnow, Robert. Communities of Discourse: Ideology and Social Structure in the Reformation, the Enligthment, and Europen Socialism. Cambridge: Harvard University Press, 1989.

Yves, Gonzalez-Quijano. Les gens du Livre: Edition et champ intellectual dans l'Egypte Republicane. Paris: CNRS Editions, 1998. 